the cathode begins to be atomized and a black deposit forms on the glass walls. The tube should then be replaced. The tubes are short and mounted in reflectors which considerably increase the efficiency of the irradiation.

Photographs are given which show the effects produced by subjecting flowering plants and strawberry beds to irradiation for periods up to three months at eight hours per night in mid-winter. Compared with plants which have not been treated in this way, the forcing effect is very pronounced.

\section{Power and Light for North Wales}

A

$\mathrm{N}$ interesting article on power and light in North Wales by Brig.-General R. F. Legge, manager of the British Power and Light Corporation, Ltd., appeared in the December issue of Trade and Engineering, a monthly review of industrial progress, issued by The Times. A subsidiary of this company called the North Wales Power Co., which generates all its electricity from water-power, supplies the north of Wales. The area over which the North Wales Power Company operates covers more than 4,000 square miles. The supply is practically unlimited and the price compares favourably with most other industrial areas in Great Britain.

The full exploitation of this area and to a great extent the well-being of its inhabitants depend largely on sound electrical development. Not only has the North Wales Power Company its own water resources, drawn from its lakes in the Snowdonia mountain ranges, on which it has spent several millions in recent years, but also its transmission system has been linked with that of the Central Electricity Board at Crewe. Hence although at present the hydro-electric system is capable of meeting continuous demands, the whole supply is safeguarded by this link with the national Grid and its controlled steam stations. By agreement with the Central Electricity Board, the output of two of the hydro-electric generating stations of the North Wales Co. is controlled and purchased by the British Power and Light Corporation, from which the North Wales Co. repurchases its requirements. In this way the stations are used by the North Wales Co. for peak load operation and supplement the Board's system by meeting the fluctuating demand at various times of the day.

There are more than 1,000 miles of high-tension distribution lines and 300 miles of low-tension, excluding the systems of eighteen local authorities which are supplied in bulk. The North Wales Power Co. itself distributes to some 300 points within the area, affording supplies to more than 150 townships, to rural villages and to independent farms.

The principal industries in North Wales are the quarrying of slate, granite and limestone, the mining of coal, lead and gold, the manufacture of bricks and tiles, wool textiles, artificial silk and chemicals, and agriculture. According to the annual report of the Secretary of Mines, in 1935 the production of slate in Great Britain was the highest for more than twenty years, and the best slate comes from North Wales. The aggregate power required for working the granite and slate quarries is 20,000 h.p. The L.M.S. Railway at Crewe has a connected load of approximately 16,000 h.p. Extensive developments have taken place in milk food production factories. The local farmers in distant rural districts are avail. ing themselves of the power companies' supply for milking and other farm work. In 1914, the Marconi Telegraph Co. erected at Caernarvon the first long-distance transmitting station to be built in Great Britain. It is still in operation, the North Wales Power Co. supplying it with the necessary current.

The diversity of the loads supplied to the various industries is very beneficial. This is seen by the load factor being about $0 \cdot 56$. During the last three years, purchases per annum have increased from 35 to 106 million units.

\section{University Events}

Brrmingham.-Mr. A. E. Hills, the donor of the new chemistry block, has made a further benefaction of $£ 25,000$, to be used for the provision of post. graduate scholarships open to all students of the University, in any faculty, who have taken a bachelor's degree and shown themselves qualified for post. graduate work. The minimum value of a scholarship is to be $£ 150$, but the Council may at its discretion increase the sum. The maximum period of tenure is two years, and the scholarships may be used for study in Leeds or any other place approved by the Council of the University. They will be known as the A. E. Hills post-graduate scholarships.

Dr. R. Peierls, assistant-in-research at the Royal Society Mond Laboratory, Cambridge, has been appointed to the newly instituted chair of applied mathematics as from October 1.

LeEds.--In the recently issued annual report, the significance of the outstanding benefaction of the year, a gift of $£ 50,000$ from an old student of the University, Mr. Frank Parkinson, is stressed. The object of the gift is to establish an endowment found for scholarships and it is noteworthy, apart from its magnitude, for the guiding principle prescribed by the donor for the administration of the fund. Educa. tion for citizenship is, he holds, a university's highest service to the community. His gift is intended "to fructify in the development of those types of manhood and womanhood which the country needs if it is to hold its place amongst the nations in the strenuous years that lie ahead", and he asks that in selecting beneficiaries the University be mindful of the supreme importance of "keeping the realities of life and the need for breadth of vision in human affairs well before its students"'.

Among the important developments of the year were the completion of the great new Library, the Brotherton, additions to the staff of the school of medicine and the inauguration of a scheme for closer co-operation with Yorkshire theological colleges. Student enrolments have steadily increased since 1930-31 and in the last session reached the record figure of 2,161 (full-time, 1,663). Nor do there seem to be grounds for fearing that the number is excessive in relation to the opportunities for employment open to graduates. On the contrary, year by year, says the report, we see an increasing reliance upon the value of university education on the part of the public. 